\title{
Pocket Atlas of Women (Kieszonkowy atlas kobiet)
}

Author: Sylwia Chutnik

First Published: 2008

Translations: German (Weibskram, 2011); Lithuanian (Kišeninis moterų atlasas, 2011); Russian (Karmannyj atlas ženštin, 2011); Slovak (Vreckový atlas žien, 2011); Serbian (Džepni atlas žena, 2013); Czech (Kapesní atlas žen, 2014); Hungarian (Nöi zsebatlasz, 2015).

Theatre Adaptation: Teatr Powszechny im. Zygmunta Hübnera, Warsaw, directed by Waldemar Śmigasiewicz, premiered on 6 March 2009.

About the Author: Sylwia Chutnik (1979) holds a Ph.D. in humanities and is a graduate of cultural studies and post-graduate of gender studies at Warsaw University. She is also a writer, journalist, city guide in Warsaw, social activist, and co-founder and chairwoman of MaMa Foundation, a Polish organisation that advocates for women's rights. She is the co-author of the documentary The Uprising in a Paisley Blouse: The Everyday Life of Women During the Warsaw Uprising, as part of the Virtual Museum of the History of Women. In her prose she tends to combine subjects related to women, history and the city. Warsaw, with its historical and cultural trauma, holds a special place in Chutnik's work.

Further Important Publications: Dzidzia (Diddums, 2009; novel); Warszawa kobiet (Female Warsaw, 2011; essays); Cwaniary (Cunning Girls, 2012; novel); W krainie czarów (In Wonderland, 2014; novel).

\section{Content and Interpretation}

Military Courier (Łączniczka) is one of four short stories included into Pocket Atlas of Women, a debut collection by Sylwia Chutnik. The protagonists of the book share the address: they are all inhabitants of a tenement house built before World War II in Warsaw's district of Ochota, 104 Opaczewska Street. The female characters of the book also share their Christian name - or, to be more precise, different variations in the name Maria. We first meet the eighty-two-year-old Maria Wachelberska in an out-patient clinic before picking up the thread of her life during the war, starting at the age of fifteen when she spent a year in a cellar, and was later forced to move to the ghetto. Her narration is characterised by understatement, as we see for example in her comments on the ghetto uprising and loss of her father: "She returned later to Opaczewska Street only with her mother” (Chutnik, 2013, p. 75). In August 1944, in the cellar at Opaczewska Street all her neighbours were killed while Maria and her mother miraculously survived - a trauma from which she never recovered: "From that time on, all

2 Open Access. () 2021 Joanna Brodniewicz, published by De Gruyter. (c) BY-NC-ND This work is licensed under a Creative Commons Attribution-NonCommercial-NoDerivatives 4.0 License. https://doi.org/10.1515/9783110671056-080 
she was waiting for was death” (p. 75). At the end of the Warsaw Uprising, the two women were expelled to Zieleniak (vegetable market place in Ochota) where the protagonist was exposed to more "collateral damage” (p. 78) of the war, namely her mother's rape and death in the course of saving Maria's life (p. 78). Maria never stopped blaming herself for that. In the Warsaw Uprising, she was a military courier in the city's canals and went every day to Zieleniak market place in Ochota: "The visits to the market are reminiscent of picking at your scab [...] 'Look, remember!”” (p. 78). She shares her memories with the other patients in the clinic: "The uprising breaks my back, all that patriotism makes my legs ache” (p. 79). Even now she never mentions her Jewish identity: "My name is Maria Wachelberska, never Wachelberg. During war I lived in Żoliborz in Warsaw, never in the ghetto. On the nineteenth of April 1943, my neighbours and I kept saying: 'Oh, the poor Jews are burning'. I did not fight.” (p. 80). Ubiquitous manifestations of antisemitism elicit feelings of fear and terror, and she knows that anyone could carry out an attack. The most good-natured saleslady in a vegetable shop, for example, a woman who has always set aside the best apples for Maria, may one day say, "This is all because of the bloody Jews" (p. 80). Maria tries to conceal her Jewish identity. Memories of the uprising in the ghetto bring about a sense of loss as well as complications in Polish-Jewish relations, primarily with regard to inequality and familiarity:

Back there, in the ghetto? What did I gain? The whole area was levelled, the few who survived were executed. Besides, it seems like nobody in Warsaw believed in that uprising. There is only room for one heroic spurt in this city - it has its museum, its martyrdom, a place of remembrance. I have also contributed to creating this history. I even offered my red and white armband for the collection when souvenirs were requested. Where could I donate my Star of David armband? I kept them together, one next to the other. Touching each other like two lovers. [...]. When I was running from the ghetto through canals, I forgot to take the Star off. Only upon leaving a canal, did a friend pull it off and put it in his pocket. If Poles had noticed it... I am not 'that' canal rat, I am a military courier from 1944. (pp. 81-82)

On the one hand, she has hidden her Jewish origin, always running away from it and, on the other, she denied the widespread evidence of antisemitism in everyday Polish life. She has lived in fear - irrationally - of being exposed. At the same time, she feels compelled to explain the reasons for her patriotism, for her service in the Home Army (Armia Krajowa), as a military and canal courier: "I knew the canals, I used them to leave the ghetto. I wanted to do something“ (p. 87). After the war, it was difficult for Maria to start life over from scratch. She vegetated, suspended between life and death. The discrepancy between what was going on in Maria's conscience and other people's evaluation of reality intensified her sense of exclusion. Her traumas turned her into a living dead: "Do not get involved with life again. [...] Do not commit or get excited. Wait it out” (p. 93). Waiting for death gave sense to her existence. "Is there a penalty worse than survival?” (p. 87). As a teenager, her life was overridden by feelings of dread, always in fear of other people's cruelty, always hiding her Jewish identity, always living in the past. These feelings culminate in her return to the cellar where she 
hid with her mother and neighbours during the war. It is yet another confrontation with death. The gesture remains unnoticed. It is a call for respect and a dignified life: the old heroes have slipped into oblivion and stagnation under inhuman conditions. She dreams one night that people killed in the war have come back and she sees herself among them. A bleeding body becomes a symbol of sacrifice to a life which she could not live to the full. She decides to act: to go down to the cellar in order to die, to help death to catch her there where others have already perished. She is returning to her roots, as if walking down to Dante's inferno. She waits for death, united with the dead: "A woman merged slowly with the walls of an old house. Bandages, sticky with blood, stuck to the wall and connected with an umbilical cord of memory" (p. 105). She has a single ambition: "To die together with the tenants from 1944. Even so long after the war. [...] She has already understood that her life, spared by fate so many times, needs to end here: in the past“ (p. 108). Maria fails to distinguish reality from dreams, through which she is guided by her mother. Her mystery play about death pulls the curtain from the stereotypes seething in society: she is backbitten, insulted, called a skimpy Jewish woman, a madwoman. Whatever she was afraid of has come back but she is above it all now. Meetings with her mother are of greatest importance: "I want to lie down here like a small embryo, put me back into your womb. Give me death, not birth" (p. 111).

\section{Main Topics and Problems}

In Pocket Atlas of Women, the author draws attention to the narrative and literary patterns that characterise her subsequent works. The issues she tackles include urban space, the war narrated from the perspective of women, and social exclusion. She returns to the motifs of the war and the post-Shoah trauma in her novel Diddums and in her short stories Muranoo and Anna as well as in a one-act play The Cellar (Piwnica, 2014). The novel's protagonist has been interpreted as "Warsaw's denied past and identity” (Uniłowski, p. 174). Warsaw, or - more precisely one of its neighbourhoods might be seen as one of the main characters of the novel. Chutnik is most interested in whatever falls outside of the official discourse: old districts, market places, venues marked by the war, a world of the excluded, people on the margins of social life (Kozicka, p. 137). The author tells the history of the war, especially that of the Warsaw Ghetto Uprising and the Warsaw Uprising, from the point of view of women (herstory) that has been marginalised in Polish historical memory. The theme of Maria's identity and her war history pose questions about memory, the long absence of the Ghetto Uprising in the national memory, and evaluation of the uprising in the context of the history of Warsaw. Her depiction of Poland equivocates between an open and multicultural society and one that is nationalistic, racist and antisemitic.

Chutnik also brings attention to the traumas faced primarily by women - depicting rape and murder as an aspect of war marked by shame and stigma (NadanaSokołowska, p. 66). Chutnik claims memory of forgotten, individual and non-heroic tragedies. She reconstructs places of gang rapes and canals leading from the ghetto 
and the Warsaw Uprising alike. She fills the pages of women's war history, female insurgents. The author also re-interprets the psychoanalytical theories concerning separation from the mother (Lacan, Kristeva). The writer also offers up some sort of a litany made up of epithets describing Maria and her world: Mother of all mothers, Windowsill Madonna, Witches guarding the world, Custodians, etc. - inscribes the figure of Maria into the context of Marian devotions in all their implications regarding women's role and duties. Chutnik provokes a dispute over Marian devotions in Poland. How has Virgin Mary come to be a symbol of Polish women? How much does she inspire them? To what extent is the model of a Polish mother still of significance in Polish culture? This raises further questions concerning the treatment of women in Poland, the sense of reverence that surrounds them, and the respect for their boundaries. Like other protagonists in the collection of short stories, the main heroine is governed by laws of human fate manifested through types and allegories (Uniłowski, p. 176). Chutnik also makes references to the world of romantic ballads (p. 178) making use of the social function of the ballad, moreover, as a voice of the marginalised (Kozicka, p. 138). She deals with other, frequently conflicting conventions: biased prose, stories, critical realism, reportage, magical realism, and parable (Uniłowski, pp. 178, 179, 181-182). Juxtaposed to these loftier literary conventions, there are also references to A. A. Milne's Winnie-the-Pooh (Uniłowski, pp. 179, 180), and - in the conceptual aspect of her work - the works of Elfriede Jelinek. The novel's language is informal, it is a spoken language which registers the reality around without judging or stigmatising; and drawing at times on bricolage, combining heterogeneous types of language (Korczyńska-Partyka, 2015, p. 246). Her writing is characterised by distance, irony, close attention to the protagonists, and anthropological sensitivity. Chutnik also tends to subvert stereotypical meanings and to cross the boundaries of excluded worlds. The text's virtue is its social and ideological impact which reinforces the mythopoeic function of a story; its drawbacks include simplifications, bias and black and white clichés.

\section{Cited Works}

Chutnik (2013). Kieszonkowy atlas kobiet. Warszawa: Świat Książki. Korczyńska-Partyka, D. (2015). Pisanie w poprzek dyskursów. Emancypacyjny potencjał prozy Sylwii Chutnik. Jednak książki. Gdańskie czasopismo humanistyczne. O Młodej Polsce mniej znanej, (4), pp. 239-251. Kozicka, D. (2015). Sylwia Chutnik, czyli kobieta w mieście. Śląskie Studia Polonistyczne, 1(6), pp. 131-142. Nadana-Sokołowska, K. (2017). Kieszonkowy atlas kobiet, Dzidzia, Cwaniary... - wybrane powieści Sylwii Chutnik w kontekście badań nad związkami reprezentacji wojny i płci kulturowej. Białostockie Studia Literaturoznawcze, (10), pp. 59-72. Uniłowski, K. (2015). Niesamowite i dowcipne. O "Kieszonkowym atlasie kobiet Sylwii Chutnik“. Śląskie Studia Polonistyczne, 1(6), pp. 171-187. 


\section{Further References}

Bałaga, M. (2016). W imieniu kobiet podziemnych: o twórczości Sylwii Chutnik. In: A. Nęcka, D. Nowacki, J. Pasterska, eds., Skład osobowy: szkice o prozaikach wspótczesnych, vol. 2. Katowice: Wydawnictwo Uniwersytetu Śląskiego, pp. 125-142. Chutnik, S. (2014). Zabawy w pamięć i gendrowy model miasta. Próba konceptualizacji praktycznej. Teksty Drugie, 25(6), pp. 116-128. Chutnik, S. http://sylwiachutnik.pl/ [Accessed: 05.08.2020]. Darska, B. (2010). Produkcyjniak społecznie zaangażowany. Opcje, (1), p. 84. Ubertowska, A. (2011). Archeologie pamięci. Współczesne kobiece narracje o wojnie. In: Z. Majchrowski, W. Owczarski, eds.,Wojna i postpamięć. Gdańsk: Wydawnictwo Uniwersytetu Gdańskiego, pp. 187-198. 